\title{
Zooplankton distribution in a mesophotic corals reef habitat at Bajo Frijol seamount, Colombian Caribbean
}

\author{
Laura Contreras-Vega*1, Alejandro Henao-Castro ${ }^{1}$, Gabriel R. Navas-S ${ }^{2}$
}

\section{Edited by}

Juan Carlos Salcedo-Reyes

salcedo.juan@javeriana.edu.co

1. University of Cartagena, Faculty of Exact and Natural Sciences, Biology Program, Descriptive and Applied Biology Research Group, Cra. 50 \#24120, Cartagena, Colombia. 130014

2. University of Cartagena, Faculty of Exact and Natural Sciences, Biology Program, Hydrobiology Research Group, Cra. 50 \#24120, Cartagena, Colombia. 130014

*lcontrerasv@unicartagena.edu.co

Received: $16-09-2020$

Accepted: 05-08-2021

Published online: 11-09-2021

Citation: Contreras-Vega L, Henao-Castro A, Navas-S GR. Zooplankton distribution in a mesophotic corals reef habitat at Bajo Frijol seamount, Colombian Caribbean, Universitas Scientiarum, 26(3): 281-300, 2021.

doi: 10.11144/Javeriana.SC26-3.zdia

Funding: National Natural Parks of Colombia (memorandum 20152200002063 11-25-15) and the Research Vice-chancellor of the University of Cartagena, Plan de Fortalecimiento Act 024-2019 and the internal research project grant 2420.

Electronic supplementary material: n.a.

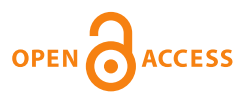

\begin{abstract}
Mesophotic coral ecosystems (MCEs) shelter unique communities. Coral zooxanthellae in these environments feature a low photosynthesis rate; therefore zooplankton becomes MCEs' primary food source. These MCEs have not been studied enough due to the high cost of current assessment technologies, so these endeavours remain a challenge. The purpose of this work was to study the zooplankton community associated to the MCEs on seamount Bajo Frijol, within the Corales de Profundidad National Natural Park (off the Colombian Caribbean coast) and to compare its composition with that from shallower parts of the water column. Three samples were taken, filtering $24 \mathrm{~L}$ of seawater (via a mesh of size $45 \mu \mathrm{m}$ ) at each station with a device designed to collect zooplankton right on top of the reef substrate. Taxonomic composition, density and relative abundance were obtained. A resemblance analysis was performed, complemented with a cluster, an MDS and a modified Kandoorp test. The analysis showed clear differences between the water column samples from those taken close to the reef. It also showed the separation of the community into two large groups: north and center-south, both with unique species.
\end{abstract}

Keywords: deep-sea corals; deep-sea protected areas; mesophotic corals; mesophotic ecosystems; zooplankton community; zooplankton distribution.

\section{Introduction}

Mesophotic coral ecosystems (MCEs) consist of light-dependent corals, usually found at depths of $30 \mathrm{~m}$-at the euphotic zone limit- where light incidence is $<1 \%$. These ecosystems are a direct extension of shallow reefs, harboring a high richness and biodiversity in their benthic habitat; furthermore, MCE communities reveal unique structures (Kahng et al., 2010, 2014; Laverick et al., 2017; Enrichetti et al., 2019).

MCEs are research and conservation hotspots because of their role as potential refuges. Along with deep coral reefs, MCEs act as source and receptors of fish larvae from shallow zones during or after a perturbation, protect a high number of species, and play an important role in the physical and biological interactions of the trophic structure (Semmler et al., 2017; Shlesinger et al., 2018; Sánchez et al., 2019).

Due to the scarce light, MCEs species have adapted to low photosynthetically active radiation (PAR). Lesser et al. (2009); Bessell-Browne et al. (2014), and Nir et al. (2014) suggested that some mesophotic corals change their trophic strategy to counteract the reduction in calcification, resulting from zooxanthellae's low photosynthetic rate, by increasing heterotrophy and, in some cases, feeding only on zooplankton. In such cases, the latter have been regarded as key organisms 
to energy transference within MCEs and as energy links between the water column and benthos. Therefore, it is necessary to understand the ecological processes that allow the existence of such unique environments.

Zooplankton consists of a large assemblage of heterotrophic organisms, mostly microscopic and with limited motion capability. These organisms are widely distributed across world's oceans, and are essential for the maintenance of reef ecosystems. Zooplankton constitutes a link between primary production and higher trophic levels, participating in biogeochemical cycles and in benthic and pelagic recruitment (Baéz-Polo, 2013; Carrillo-Baltodano and Morales-Ramírez, 2016; Nakajima et al., 2017; Lorda et al., 2019; MacKenzie et al., 2019).

Research conducted on MCEs has mainly focused on sessile organisms, like scleractinian corals, octocorals, and sponges, as well as on mobile organisms like fishes (Kahng et al., 2014; Scott and Pawlik, 2019); only few authors have addressed zooplankton organisms. Andradi-Brown et al. (2016) recently reported the first comparison between zooplankton communities associated with mesophotic and shallow reefs, concluding that further investigation is necessary to understand the distribution pattern of zooplankton communities in MCEs.

Corales de Profundidad National Natural Park (PNNCPR) is the first marine protected area of deep zones in Colombia (Alonso et al., 2015). Given the ecological importance of zooplankton and its use as a biological indicator, PNNCPR has prioritized zooplankton study, within a monitoring program. The purpose of this work was to analyze the distribution of the zooplankton community associated with MCEs on the seamount Bajo Frijol, located in PNNCPR's protected area, comparing its composition with the zooplankton community from shallower parts of the water column.

\section{Methods}

\subsection{Studied area}

PNNCPR is located in the Colombian Caribbean, across from the Archipelago of San Bernardo. It has an extension of $142192 \mathrm{~km}^{2}$ and its depth ranges from $31 \mathrm{~m}$ to $1240 \mathrm{~m}$ (Morales et al., 2017). Within this marine protected area, the seamount Bajo Frijol was chosen as study area (Figure 1).

Bajo Frijol is located at the edge of the Colombian Caribbean continental shelf and has a mostly flat bottom at a depth of $36 \mathrm{~m}$ and mainly covered by calcareous rhodoliths. At Bajo Frijol's shallowest point, around $32 \mathrm{~m}$ deep, some coral colonies and hard coralline landforms are present. Said landforms adjoin with flat zones a little deeper (down to $40 \mathrm{~m}$ ) with isolated coral and sponge promontories. This zone boasts fish richness and abundance (Chasqui and Gonzalez, 2019).

As for zooplankton, Gutiérrez (2010) has reported around Islas del Rosario -an oceanic zone close to Bajo Frijol- dominance of copepods (68\%), followed by appendicularians (23\%). On deeper zones, copepods are still dominant (75\%) and are followed by ostracods (15\%). Chaetognates and other groups account for $3 \%$ of the zooplankton. Medellín-Mora and Martínez-Ramírez (2010) also reported at a station close to PNNCPR a dominance of copepods (82 793 individuals / 100 $\mathrm{m}^{3}$ ), followed by appendicularians (10738 individuals $\left./ 100 \mathrm{~m}^{3}\right)$, and echinoderm larvae (4677 individuals $/ 100 \mathrm{~m}^{3}$ ). A net with mesh size of $200 \mu \mathrm{m}$ was used on both studies. 


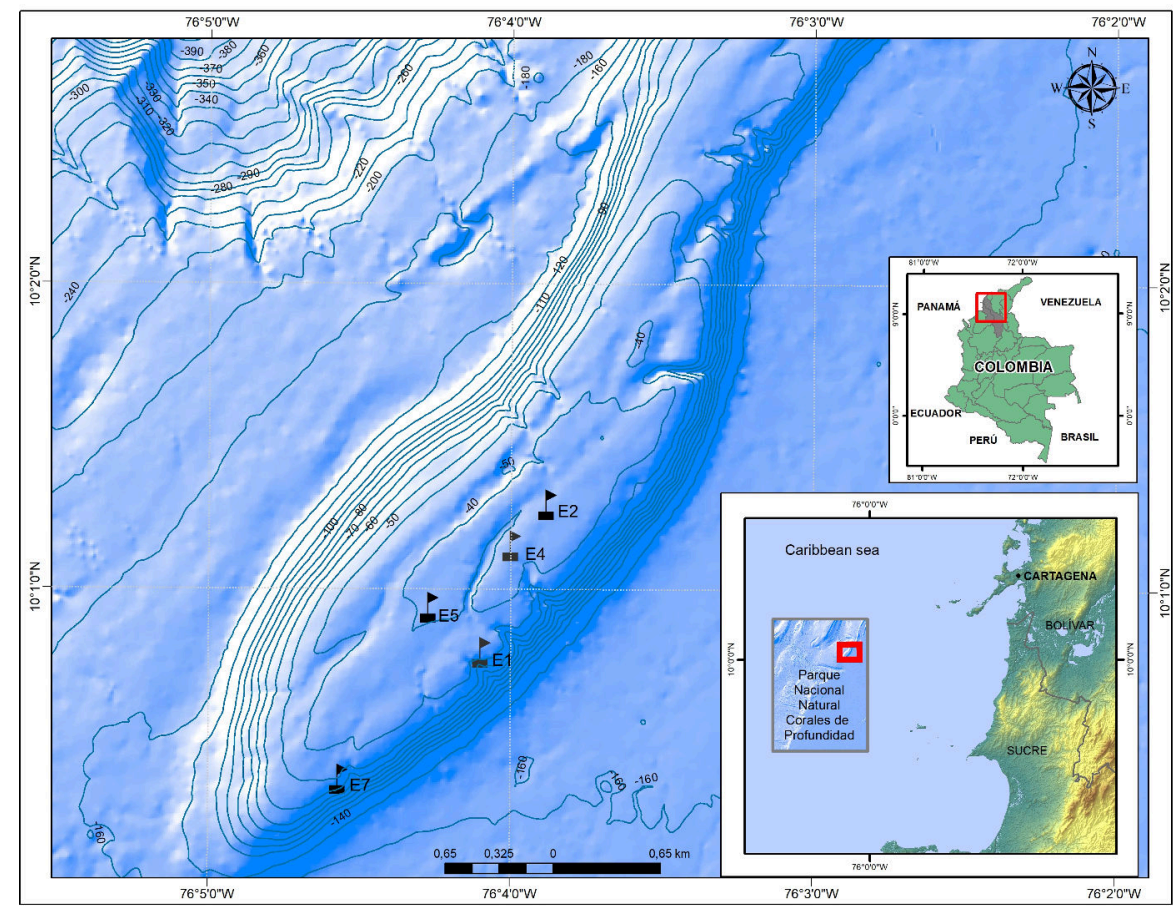

Figure 1. Map of the seamount Bajo Frijol, within PNNCPR. Sampling sites are marked and numbered.

\subsection{Sample collection and analysis}

Five sites were chosen for sample collection, with depths between $35 \mathrm{~m}$ and $70 \mathrm{~m}$, trying to cover most of the seamount area (Figure 1). Diurnal samplings took place in the five stations in August (E1, E5, and E7) and December (E2 and E4) 2016. Three samples were taken at each station using a device (Figure 2) designed to collect zooplankton samples right on top the mesophotic reef substrate (Contreras-Vega et al., 2020). The sampling device filters $24 \mathrm{dm}^{3}$ of sea water with a mesh size of $45 \mu \mathrm{m}$, and recovers an extract of $250 \mathrm{~cm}^{3}$ into plastic bottles. Zooplankton samples were preserved with $4 \%$ formalin neutralized with borax (Baéz-Polo, 2013). Two additional samples were collected to assess the zooplankton community in the upper zones of the water column and serve as references in the study; R1 at station E1, and R2 at station E2, at $15 \mathrm{~m}$ and $5 \mathrm{~m}$ depth, respectively.

Following Boltovskoy (1981), each sample was sedimented for $72 \mathrm{~h}$. A $50 \mathrm{~cm}^{3}$ extract was used for specimen observation under an optical microscope with $100 \times$ magnification. Each entire sample was assessed through aliquots on a Bogorov plate. Taxonomic identification of zooplankton was conducted with the following guides: Boltovskoy (1981); Zheng (1989); Fernandes (2004a,b); Johnson and Allen (2005); Figueroa et al. (2005); Costa (2006); Riviera (2006), the online data bases Dolven and Skjerpen (2007) and the World Register of Marine Species WORMS (2017). 


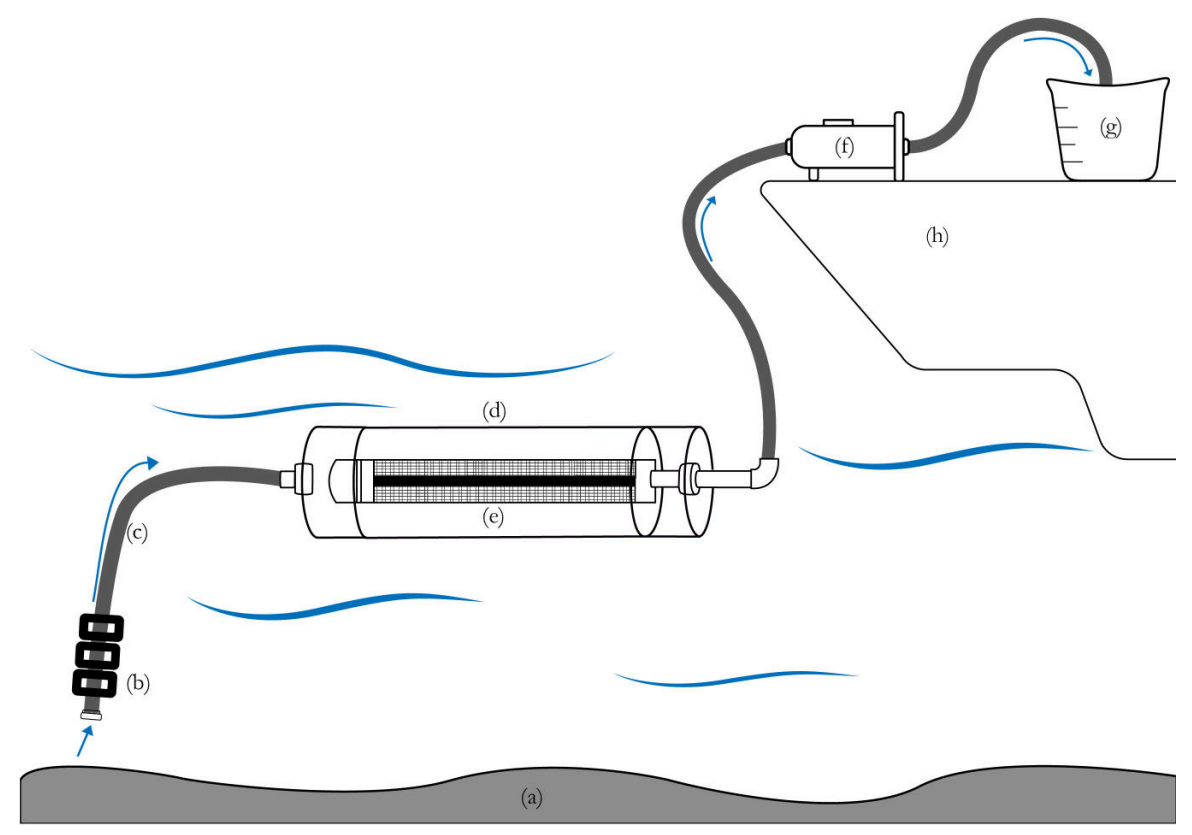

Figure 2. Collection device for mesophotic zooplankton. The device was built based on a pumping system, which allows for access to the water column without leaving the sampling boat. The device filters a known volume through a net of $45 \mu \mathrm{m}$ mesh size. (a) Reef substrate; (b) Ballast weight; (c) Hose; (d) Vacuum creator; (e) Collector tube; (f) Centrifugal pump; (g) Volumetric container; (h) Sampling boat.

\subsection{Data analysis}

An abundance matrix was built by taxon for each station to describe the composition and ecological attributes of the community. These matrices were used to estimate the percentage abundance and overall and station-wise species richness. An ecological attribute analysis (Shannon-Wiener diversity, Pielou's uniformity and Simpson's predominance) was run for each station. The following equation was used to calculate zooplankton density (individuals $/ \mathrm{m}^{3}$ ):

$$
\text { Density }=\frac{N}{V},
$$

where $N=$ Abundance and $V=$ Filtered volume $\left(\mathrm{m}^{3}\right)$.

To study the distribution of zooplanktonic assemblages in Bajo Frijol, a similarity test ANOSIM was run to determine if there were significant differences between sampling stations (Clarke et al., 2014). Additionally, a resemblance matrix between samples was calculated using the Bray-Curtis similarity index, data were fourth root transformed to guarantee that the program showed the composition similarities of the entire community, given that most of the identified taxa had very low abundances while others were too high (Clarke et al., 2014). The resemblance matrix was complemented with a classification analysis (cluster), using a SIMPROF test and a multidimensional scaling analysis (MDS) to observe the aggrupation and ordination of the samples.

In addition, a modified inverse analysis (Kaandorp, 1986; Navas et al., 2010) was performed. This consisted of a new abundance matrix by taxon for each group obtained in the Bray-Curtis cluster, which was used to estimate the percentage abundance, species richness, density and frequency, 
as well as the generalist and exclusive species for each assemblage. An ecological-attribute analysis (including Shannon-Wiener diversity Mean, Pielou's uniformity Mean and Simpson's predominance Mean) was run first for each group obtained in the Bray-Curtis cluster, this time including the reference samples. All ecological tests were performed using the statistical software PRIMER-E V7.

\section{Results and Discussion}

\subsection{Community composition and density}

A total of 123 taxa (114 species, 9 larvae) were identified, grouped in 19 zooplankton groups: Amphipoda, Appendicularia, Bryozoa, Cnidarian larvae, Copepoda, Doliolida, Echinoderm larvae, Foraminifera, Hydrozoa, Nauplii, Ostracoda, Polychaeta, Protozoea, Pteropoda, Radiolaria, Rotifera, Siphonophora, Tintinida, and Veliger of Mollusca.

Tintinnids revealed the greatest richness (33 species), followed by radiolarians with 32 species. These groups are the most diverse in tropical zones, having high richness and low abundance. The latter, however, tends to increase with depth (Anderson, 1994; Armstrong and Brasier, 2005). Copepods had 24 species (Table 1), mostly calanoids, similar to those reported by Gutiérrez (2010) and Medellín-Mora and Martínez-Ramírez (2010) in an area close to that assessed in the present study.

Table 1. Total richness $(S)$, density (individuals $/ \mathrm{m}^{3}$ ) and abundance of each identified zooplankton group.

\begin{tabular}{lccc}
\hline Zooplankton group & $S$ & Density & Abundance (\%) \\
\hline Amphipoda & 1 & 111 & 0.19 \\
Appendicularia & 2 & 2611 & 4.46 \\
Bryozoa & 1 & 97 & 0.17 \\
Cnidarian larvae & 2 & 361 & 0.62 \\
Copepoda & 24 & 6361 & 10.87 \\
Decapod larvae & 1 & 28 & 0.05 \\
Doliolida & 1 & 14 & 0.02 \\
Echinoderm larvae & 3 & 153 & 0.26 \\
Foraminifera & 14 & 8875 & 15.16 \\
Hydrozoa & 1 & 194 & 0.33 \\
Nauplii & 1 & 23028 & 39.34 \\
Ostracoda & 1 & 1014 & 1.73 \\
Polychaeta & 1 & 181 & 0.31 \\
Pteropoda & 1 & 125 & 0.21 \\
Radiolaria & 32 & 3889 & 6.64 \\
Rotifera & 1 & 292 & 0.50 \\
Siphonophora & 1 & 28 & 0.05 \\
Tintinida & 33 & 9653 & 16.49 \\
Veliger of Mollusca & 2 & 1528 & 2.61 \\
\hline
\end{tabular}

As to density, a total of 58543 individuals $/ \mathrm{m}^{3}$ were identified. Nauplii had the major abundance with $39.34 \%$ (23028 individuals $/ \mathrm{m}^{3}$, showing continuous reproductive cycles, typical for tropical species (Boltovskoy, 1981). These organisms can exceed copepodites and some adult 
copepods in number (Thompson, 2001; Thompson et al., 2013) just as observed in Bajo Frijol (Table 1). Tintinnids had a share of $16.49 \%$ (9653 individuals $/ \mathrm{m}^{3}$ ), being one of the main groups of microzooplankton. Tintinnids are central to secondary production in all seas (Boltovskoy, 1981; Pierce and Turner, 1993; Thompson et al., 1999; Thompson, 2001). Foraminiferans and copepods also had a significant abundance with $15.16 \%$ and $10.87 \%$ (8875 individuals $/ \mathrm{m}^{3}$ and 6361 individuals $/ \mathrm{m}^{3}$ ), respectively (Table 1 ).

\subsection{Composition and density per sampling site}

Station E1, located at the center of the seamount, was the richest of all stations with 85 taxa. This station basted the highest richness of radiolarians ( 23 species). Tintinnids, copepods and foraminifers also had a high richness $(16,15$, and 12 species, respectively). E7, located at the south of the seamount, had the highest number of copepods (21 species), whereas E4, located at the north, had the most of tintinnids species (20 species). E2, located at the north, revealed the lowest total richness (70 species), preceded by E4 and E7 having similar richness (72 species each) (Table 2 and Table 3).

As to density, E1 had the highest overall abundance (14000 individuals $/ \mathrm{m}^{3}$ ), followed by E5 and E7 with 12819 individuals $/ \mathrm{m}^{3}$ and 12431 individuals $/ \mathrm{m}^{3}$, respectively. E7 had the highest abundance of copepods ( 1694 individuals $/ \mathrm{m}^{3}$ ), and foraminiferans ( 2931 individuals $/ \mathrm{m}^{3}$ ) (Tables 2 and 3). E4 had the highest density of Appendicularians, with 1194 individuals $/ \mathrm{m}^{3}$, while E1 and E7 has the highest density of mollusc veliger. Nauplii dominated in all the stations. Tintinnids, radiolarians, foraminiferans and copepods were identified abundantly on each station (Table 2).

Table 2. Zooplankton group density $(N)$ individuals $/ \mathrm{m}^{3}$ and richness $(S)$ by station.

\begin{tabular}{|c|c|c|c|c|c|c|c|c|c|c|}
\hline \multirow{2}{*}{ Zooplankton group } & \multicolumn{2}{|c|}{ E1 } & \multicolumn{2}{|c|}{ E2 } & \multicolumn{2}{|c|}{ E4 } & \multicolumn{2}{|c|}{ E5 } & \multicolumn{2}{|c|}{ E7 } \\
\hline & $N$ & $S$ & $N$ & $S$ & $N$ & $S$ & $N$ & $S$ & $N$ & $S$ \\
\hline Amphipoda & 28 & 1 & 69 & 1 & 0 & 0 & 14 & 1 & 0 & 1 \\
\hline Appendicularia & 417 & 2 & 250 & 2 & 1194 & 2 & 472 & 2 & 278 & 2 \\
\hline Briozoa & 14 & 1 & 0 & 0 & 0 & 0 & 83 & 1 & 0 & 0 \\
\hline Cnidarian larvae & 222 & 2 & 28 & 1 & 42 & 2 & 14 & 1 & 56 & 2 \\
\hline Copepoda & 1000 & 15 & 1125 & 14 & 1292 & 12 & 1250 & 15 & 1694 & 20 \\
\hline Decapod larvae & 0 & 0 & 0 & 0 & 14 & 1 & 14 & 1 & 0 & 0 \\
\hline Doliolida & 0 & 0 & 0 & 0 & 0 & 0 & 0 & 0 & 14 & 1 \\
\hline Echinoderm larvae & 28 & 2 & 14 & 1 & 28 & 1 & 42 & 2 & 42 & 2 \\
\hline Foraminifera & 2403 & 12 & 944 & 9 & 944 & 9 & 1653 & 11 & 2931 & 12 \\
\hline Hydrozoa & 28 & 1 & 0 & 0 & 0 & 0 & 83 & 1 & 83 & 1 \\
\hline Nauplii & 4917 & 1 & 3639 & 1 & 3750 & 1 & 6056 & 1 & 4667 & 1 \\
\hline Ostracoda & 278 & 1 & 236 & 1 & 125 & 1 & 125 & 1 & 250 & 1 \\
\hline Polychaeta & 42 & 1 & 28 & 1 & 111 & 1 & 0 & 0 & 0 & 0 \\
\hline Pteropoda & 42 & 1 & 28 & 1 & 14 & 1 & 28 & 1 & 14 & 1 \\
\hline Radiolaria & 1319 & 23 & 806 & 19 & 806 & 18 & 528 & 11 & 431 & 10 \\
\hline Rotifera & 167 & 1 & 42 & 1 & 0 & 0 & 83 & 1 & 0 & 0 \\
\hline Siphonophora & 14 & 1 & 0 & 0 & 0 & 0 & 0 & 0 & 14 & 1 \\
\hline Tintinida & 2653 & 16 & 1722 & 16 & 1778 & 20 & 2000 & 18 & 1500 & 15 \\
\hline Veliger of Mollusca & 431 & 2 & 83 & 2 & 208 & 2 & 375 & 2 & 431 & 2 \\
\hline
\end{tabular}


Reports on radiolarians and tintinnids in the Colombian Caribbean are scarce. This is because the net size used in most studies $(>100 \mu \mathrm{m})$ does not allow the retention of those groups (Thompson, 2001; Vanegas and Arregocés, 2015). This could also explain nauplii dominance, since nets with mesh sizes larger than $45 \mu \mathrm{m}$ (as used in the current research), would not retain early-stage individuals (Thompson, 2001), as observed in Gutiérrez (2010) and Medellín-Mora and MartínezRamírez (2010), who used a mesh size of $200 \mu \mathrm{m}$, revealing copepods, appendicularians, and decapods as the dominant groups. On the other hand, foraminiferans, are organisms with a great preference for clean waters, without suspended organic matter and with salinity between $32 \mathrm{ppt}$ and 42 ppt (Boltovskoy, 1981), as is usually found on coral reef habitats.

Copepods represent one of the largest and most important groups within zooplankton communities (due to its high richness and abundance), distributed in a cosmopolitan manner, and present in various vertical strata (Boltovskoy, 1981; Bernal and Zea, 1993; Thompson, 2001; Gutiérrez, 2010; Hernandez-Trujillo et al., 2010), which explains its presence in each of the sampled stations, with some fluctuations per station, probably due to availability of the resource or possible vertical migrations (Boltovskoy, 1981; Bernal and Zea, 1993).

Ecologic attribute analyses showed high evenness values on each station ( $J^{\prime}$ between 0.62 and 0.70) (Table 3). E1 had the highest diversity, followed by $\mathrm{E} 4\left(H^{\prime}=3.07\right.$ and $H^{\prime}=3.01$; respectively), meanwhile E5 had the lowest diversity value $\left(H^{\prime}=2.63\right)$ (Table 3$)$. E2 and E7 had comparable diversity values (2.86 and 2.91 , respectively).

\subsection{Zooplankton community distribution}

The ANOSIM showed differences between stations. However, this analysis also revealed similarities between the stations located at the center and south of the seamount (E1-E5; $R=0.11$; $p<0.3$ ), those located at the south (E5-E7; $R=0.22 ; p<0.3$ ), and the stations located at the north (E2-E4; $R=0.22 ; p<0.1)$ (Table 4).

Additionally, the Bray-Curtis resemblance cluster, complemented with a SIMPROF (cophenetic index of 0.88 and an MDS (stress 0.06) showed data clustering into four groups: A (R1), B (R2), $\mathrm{C}$ (E1, E5 and E7) and D (E2 and E4) (Figure 3).

Group A. This group consists of the reference sample (R1) collected at E2 at $5 \mathrm{~m}$ depth, which does not correspond to a mesophotic zone. This assemblage presented the greatest abundance with 45750 individuals $/ \mathrm{m}^{3}$ and richness of 79 species, three of them exclusive (the crustaceans Evadne sp., Pontellina sp., and the radiolarian Lamprocyclas sp.) (Figure 4).

Table 3. Ecological attributes per sampling site: Richness $(S)$, Density $(N)$, Pielou evenness $\left(J^{\prime}\right)$, Shannon-Wienner diversity $\left(H^{\prime}\right)$, and Simpson dominance $(\lambda)$.

\begin{tabular}{cccccc}
\hline Station & $S$ & $N$ & $J^{\prime}$ & $H^{\prime}$ & $\lambda$ \\
\hline E1 & 85 & 14000 & 0.69 & 3.07 & 0.14 \\
E2 & 70 & 9139 & 0.68 & 2.91 & 0.17 \\
E4 & 72 & 10361 & 0.70 & 3.01 & 0.15 \\
E5 & 71 & 12819 & 0.62 & 2.63 & 0.23 \\
E7 & 72 & 12431 & 0.67 & 2.86 & 0.16 \\
\hline
\end{tabular}

Universitas Scientiarum Vol. 26(3):281-300 http://ciencias.javeriana.edu.co/investigacion/universitas-scientiarum 
Table 4. Similarity analysis ANOSIM. Global $R$ of $0.681(p<0.001)$.

\begin{tabular}{cccccc}
\hline & E7 & E5 & E1 & E4 & E2 \\
\hline E7 & - & & & & \\
E5 & 0.22 & & & & \\
E1 & 0.74 & 0.11 & & & \\
E4 & 0.96 & 0.89 & 0.85 & & \\
E2 & 1 & 1 & 0.85 & 0.22 & - \\
\hline
\end{tabular}

Group B. This group consists of the reference sample (R2) from E1 collected at $15 \mathrm{~m}$ depth, which does not correspond to a mesophotic zone. This assemblage had a density of 12250 individuals $/ \mathrm{m}^{3}$ and a richness of 57 species, and it featured only two exclusive species, the tintinnid Coxliela sp. and the radiolarian Cladoscenium sp. (Figure 4).

Group C. This group assembles the stations located at the center and south of the Bajo Frijol seamount (E1, E5, and E7), as supported by the ANOSIM results. This assemblage had 76 $( \pm 4.70)$ species and an abundance of 13065 individuals $/ \mathrm{m}^{3}( \pm 453.91)$. This group had the highest number of exclusive species (20); the most frequent were the tintinnid Codonella sp. with $56 \%$ and the radiolarian Clathromitra sp. with $44 \%$ (Figure 4).

Group D. This group entails the northern stations of Bajo Frijol (E2 and E4), as revealed by the ANOSIM. This assemblage had an abundance of 9757 individuals $/ \mathrm{m}^{3}$ and a richness of 71 species. Eight exclusive species were found in this group, the most frequent of them were the tintinnid Undella globosa with $67 \%$ and Protorhabdonella simplex with $33 \%$ (Figure 4).

The upper zone of the water column, called Superficial Tropical Water Mass (AST), presents an amplitude of $35 \mathrm{~m}$ depth, and its physicochemical parameters have low variation; most of their variation occurs in the superficial layers. Following this mass of water, is the Superficial Subtropical Water Mass (ASS), starting from the AST lowest limit to the photic zone limit (150 $\mathrm{m}$ to $200 \mathrm{~m}$ ) (Longhurst, 1985). Gutiérrez (2010) found that even though the oceanic mesozooplankton community, close to Bajo Frijol, may be just one, its structure varies, firstly due to these water masses that compose the water column, and secondly, due to local outside factors specific for each area. Submarine current patterns could account for one of these factors, which may have caused a segregation of oceanic and typically neritic species to the north (group D), and oceanic and warm-water species to the center-south (group C). Given that the seamount is located at the edge of the continental shelf, as reported by Neumann-Leitão et al. (2008), the narrowness of the continental shelf and the effects of the currents and winds from the coast led communities to mix. A depth difference could have also influenced the division, because the northern assemblage is located in a shallower zone (35 $\mathrm{m}$ to $36 \mathrm{~m}$ ). In addition, the center-south assemblage presents deeper zones $(37 \mathrm{~m}, 45 \mathrm{~m}$ and $70 \mathrm{~m})$.

The complete isolation of Groups A and B, shows that MCEs also form unique communities for zooplankton, different from communities in upper zones of the water column, possibly influenced by water masses, depth and light limitations. Andradi-Brown et al. (2016) reported significant differences between the zooplankton community at an MCE and a shallow reef community in Honduras, mainly in abundance, being higher in mesophotic zones, whereas richness was fairly equal. However, in the current research, the water column's zooplankton community showed a greater abundance than the mesophotic community. This particular difference from the study made in Honduras, could be explained because coral reefs are highly biodiverse and most of its associated 

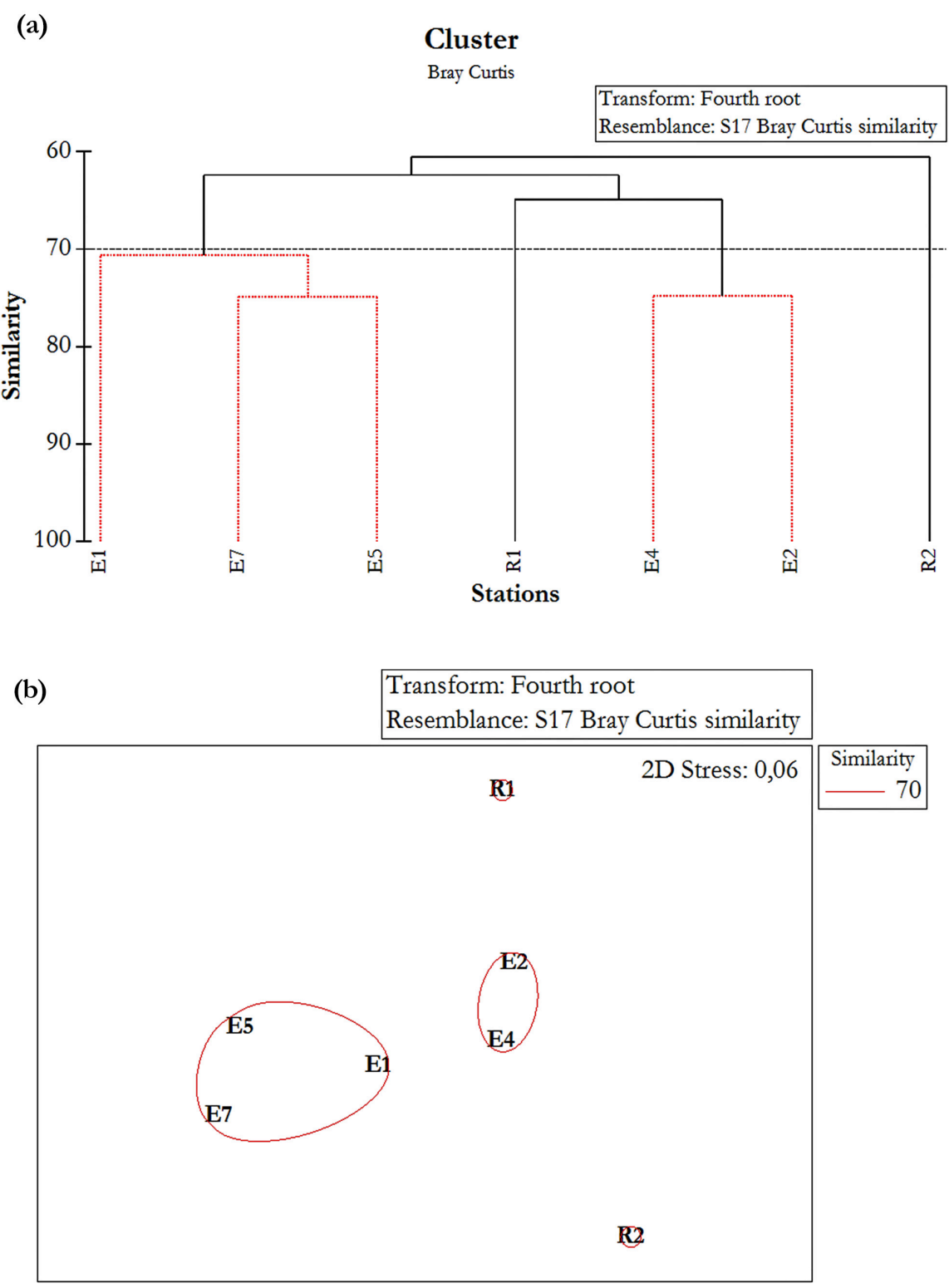

Figure 3. Classification and multidimensional scaling analysis. (a) Bray- Curtis similarity cluster complemented with a SIMPROF (Coph index. 0.88). (b) MDS (stress 0.06), this figure shows samples clustering into four groups: R1, R2, E2-E4, and E1-E5-E7. The first two groups were separated due to their depth; the third and fourth group separated by their location on the seamount.

species, like fishes, corals, among others, feed on plankton (Lesser et al., 2009; Bejarano et al., 2014; Kahng et al., 2014), likely leading to a decrease in the zooplankton abundance. Besides, plankton associated with reefs had exclusive species and some species that modify their behaviour to live in these ecosystems (Heidelberg et al., 2004). Pelagic zooplankton, on the other hand, tends to be more abundant in shallow layers (Marín et al., 2004; Gutiérrez, 2010) because some species migrate vertically to avoid predators and get food (Zaret and Suffern, 1976; Stich and Lampert, 1981; Bernal and Zea, 1993), which could also be influencing the high abundances observed in shallower zones on Bajo Frijol seamount. 
a)

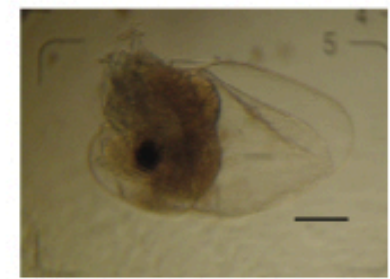

d)

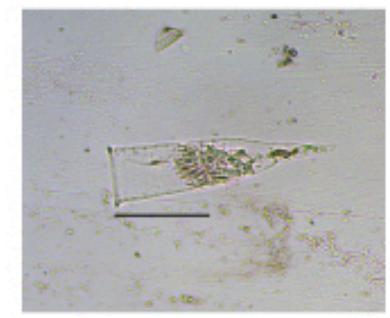

g)

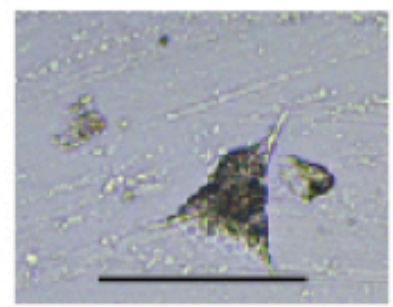

b)

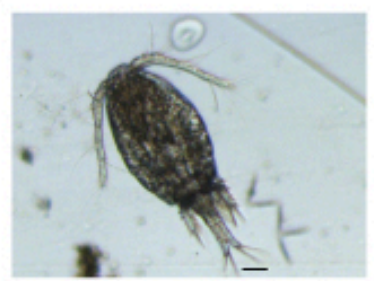

c)

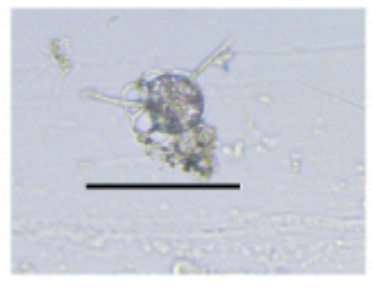

h)

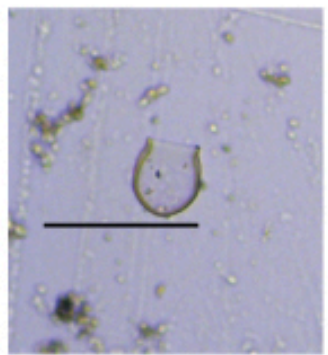

c)

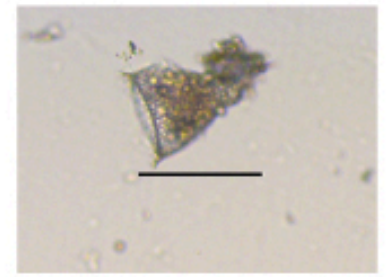

f)

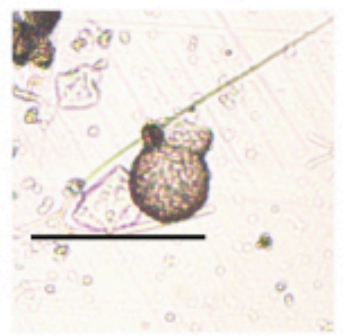

i)

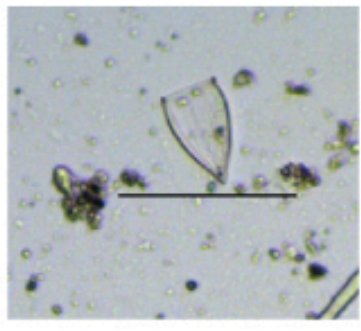

Figure 4. Exclusive species within: Group A: (a) Evadne sp., (b) Pontellina sp., (c) Lamprocyclas sp.; Group B: (d) Coxliela sp., (e) Cladoscenium sp.; Group C: (f) Codonella sp., (g) Clathromitra sp.; and Group D: (h) Undella globosa, (i) Protorhabdonella simplex.

Additionally, nine exclusive taxa for the MCE zone were identified, which means, they were present only in the assemblages $\mathrm{C}$ and $\mathrm{D}$ (Figure 5), mostly tintinnids and radiolarians. 36 generalist taxa (Table 5) were also identified, mostly copepods (9), tintinnids (8) and radiolarians (6), nine of them with an average frequency of $100 \%$. The larvae nauplii had the greatest abundance in every assemblage ( $46 \%, 40 \%, 41 \%$ and $38 \%)$.

The mesophotic community, northern and south assemblages, and the mesophotic zone in general, had tintinnids and radiolarians as exclusive species. Tintinnids are abundant organisms and can be found at depths of up to $100 \mathrm{~m}$, inhabiting various environments (Pierce and Turner, 1993; Thompson et al., 1999; Thompson, 2001); whereas, radiolarians become more frequent as depth increases, and different species appear according to the forming vertical barriers (between depths of $50 \mathrm{~m}$ and $100 \mathrm{~m}$ ). Therefore, it was expected that most of the exclusive species were among those groups (Anderson, 1994; Boltovskoy, 1981; Thompson et al., 1999; Thompson, 2001; Armstrong and Brasier, 2005).

The tintinnid Undella hyalina was identified as exclusive within assemblage C, which has been reported between $15 \mathrm{~m}$ and $30 \mathrm{~m}$ depth (Thompson, 2001), however its distribution range appears to be broader, provided that all of the $U$. hyalina samples from assemblage $\mathrm{C}$ were found in a depth range of $37 \mathrm{~m}$ to $70 \mathrm{~m}$. 
Table 5. List of generalist species found with the Kaandorp analysis. F generalist $=$ Average frequency, $N=$ Density, $N(\%)=$ Percentage abundance, $F=$ Frequency.

\begin{tabular}{|c|c|c|c|c|c|c|c|c|c|c|c|c|c|}
\hline \multirow{2}{*}{ TAXA } & \multirow{2}{*}{ F Generalist } & \multicolumn{3}{|c|}{$\mathrm{A}$} & \multicolumn{3}{|c|}{ B } & \multicolumn{3}{|c|}{$\mathrm{C}$} & \multicolumn{3}{|c|}{$\mathrm{D}$} \\
\hline & & $N$ & $N(\%)$ & $F$ & $N$ & $N(\%)$ & $F$ & $N$ & $N(\%)$ & $F$ & $N$ & $N(\%)$ & $F$ \\
\hline Oithona $\mathrm{sp}$ & 100 & 458 & 1 & 100 & 167 & 1.4 & 100 & 407 & 3.1 & 100 & 194 & 2 & 100 \\
\hline Oncaea sp & 100 & 333 & 0.7 & 100 & 125 & 1 & 100 & 218 & 1.7 & 100 & 313 & 3.2 & 100 \\
\hline Ostracoda & 100 & 1542 & 3.4 & 100 & 292 & 2.4 & 100 & 218 & 1.7 & 100 & 181 & 1.9 & 100 \\
\hline Nauplii & 100 & 21083 & 46.1 & 100 & 5042 & 41.2 & 100 & 5213 & 40 & 100 & 3694 & 37.9 & 100 \\
\hline Oikopleura sp & 100 & 2250 & 4.9 & 100 & 375 & 3.1 & 100 & 273 & 2.1 & 100 & 340 & 3.5 & 100 \\
\hline Eutintinnus medius & 100 & 1250 & 2.7 & 100 & 292 & 2.4 & 100 & 269 & 2.1 & 100 & 292 & 3 & 100 \\
\hline Salpingella $\mathrm{sp}$ & 100 & 292 & 0.6 & 100 & 417 & 3.4 & 100 & 509 & 3.9 & 100 & 132 & 1.4 & 100 \\
\hline Globigerina bulloides & 100 & 958 & 2.1 & 100 & 458 & 3.7 & 100 & 856 & 6.6 & 100 & 410 & 4.2 & 100 \\
\hline Veliger of Gasteropoda & 100 & 375 & 0.8 & 100 & 250 & 2 & 100 & 338 & 2.6 & 100 & 76 & 0.8 & 100 \\
\hline Fritillaria $\mathrm{sp}$ & 97 & 708 & 1.5 & 100 & 208 & 1.7 & 100 & 116 & 0.9 & 89 & 382 & 3.9 & 100 \\
\hline Rhabdonella spiralis & 97 & 250 & 0.5 & 100 & 42 & 0.3 & 100 & 93 & 0.7 & 89 & 201 & 2.1 & 100 \\
\hline Eutintinnus lususundae & 97 & 917 & 2 & 100 & 375 & 3.1 & 100 & 343 & 2.6 & 89 & 243 & 2.5 & 100 \\
\hline Globorotalia sp & 96 & 1833 & 4 & 100 & 333 & 2.7 & 100 & 560 & 4.3 & 100 & 222 & 2.3 & 83 \\
\hline Codonellopsis schabii & 94 & 750 & 1.6 & 100 & 125 & 1 & 100 & 88 & 0.7 & 78 & 306 & 3.1 & 100 \\
\hline Epiplocylis $\mathrm{sp}$ & 90 & 125 & 0.3 & 100 & 125 & 1 & 100 & 116 & 0.9 & 78 & 97 & 1 & 83 \\
\hline Textularia $\mathrm{sp}$ & 89 & 292 & 0.6 & 100 & 83 & 0.7 & 100 & 134 & 1 & 89 & 35 & 0.4 & 67 \\
\hline Cycladophora sp & 89 & 208 & 0.5 & 100 & 83 & 0.7 & 100 & 46 & 0.4 & 56 & 194 & 2 & 100 \\
\hline Calocalanus sp & 86 & 333 & 0.7 & 100 & 125 & 1 & 100 & 56 & 0.4 & 44 & 132 & 1.4 & 100 \\
\hline Actinomma sp & 85 & 167 & 0.4 & 100 & 42 & 0.3 & 100 & 83 & 0.6 & 89 & 28 & 0.3 & 50 \\
\hline Corycaeus sp & 82 & 708 & 1.5 & 100 & 167 & 1.4 & 100 & 106 & 0.8 & 78 & 42 & 0.4 & 50 \\
\hline Veliger of Bivalvia & 81 & 125 & 0.3 & 100 & 42 & 0.3 & 100 & 74 & 0.6 & 56 & 69 & 0.7 & 67 \\
\hline Arachnocorallium calvata & 79 & 42 & 0.1 & 100 & 167 & 1.4 & 100 & 51 & 0.4 & 33 & 63 & 0.6 & 83 \\
\hline Paracalanus $\mathrm{sp}$ & 76 & 583 & 1.3 & 100 & 83 & 0.7 & 100 & 9 & 0.1 & 22 & 125 & 1.3 & 83 \\
\hline Temora longicornis & 76 & 250 & 0.5 & 100 & 42 & 0.3 & 100 & 23 & 0.2 & 56 & 42 & 0.4 & 50 \\
\hline Actinula & 76 & 750 & 1.6 & 100 & 208 & 1.7 & 100 & 69 & 0.5 & 56 & 28 & 0.3 & 50 \\
\hline Oithona simplex & 74 & 292 & 0.6 & 100 & 42 & 0.3 & 100 & 9 & 0.1 & 11 & 69 & 0.7 & 83 \\
\hline Epiplocylis undella & 74 & 125 & 0.3 & 100 & 42 & 0.3 & 100 & 5 & 0 & 11 & 104 & 1.1 & 83 \\
\hline Arachnocorys sp & 74 & 83 & 0.2 & 100 & 42 & 0.3 & 100 & 5 & 0 & 11 & 83 & 0.9 & 83 \\
\hline Lithomelissa $\mathrm{sp}$ & 74 & 292 & 0.6 & 100 & 83 & 0.7 & 100 & 14 & 0.1 & 11 & 63 & 0.6 & 83 \\
\hline Globoquadrina $\mathrm{sp}$ & 65 & 42 & 0.1 & 100 & 125 & 1 & 100 & 46 & 0.4 & 44 & 7 & 0.1 & 17 \\
\hline Calocalanus pavo & 63 & 375 & 0.8 & 100 & 42 & 0.3 & 100 & 46 & 0.4 & 33 & 7 & 0.1 & 17 \\
\hline Macrosetella $\mathrm{sp}$ & 63 & 125 & 0.3 & 100 & 83 & 0.7 & 100 & 19 & 0.1 & 33 & 7 & 0.1 & 17 \\
\hline Planula & 63 & 83 & 0.2 & 100 & 125 & 1 & 100 & 28 & 0.2 & 33 & 7 & 0.1 & 17 \\
\hline Cenosphaera $\mathrm{sp}$ & 61 & 250 & 0.5 & 100 & 42 & 0.3 & 100 & 23 & 0.2 & 11 & 14 & 0.1 & 33 \\
\hline Nematoda & 60 & 83 & 0.2 & 100 & 42 & 0.3 & 100 & 9 & 0.1 & 22 & 14 & 0.1 & 17 \\
\hline Rotifera & 60 & 42 & 0.1 & 100 & 83 & 0.7 & 100 & 46 & 0.4 & 22 & 21 & 0.2 & 17 \\
\hline
\end{tabular}

As for generalist species, most of them were crustaceans. Crustaceans constitute the largest zooplanktonic group, with representatives of almost all of its classes and orders (Barnacles, copepods, cladocerans, ostracods, amphipods, euphausiids, among others), both as larvae and adults and in different sizes and trophic groups (Boltovskoy, 1981; Gasca and Castellanos, 1993; Thompson, 2001; Gutiérrez, 2010; Hernandez-Trujillo et al., 2010). This explains their observed frequency in all the assemblages obtained for both environments.

The ecologic attributes analysis showed high uniformity values in each assemblage ( $J^{\prime}$ between 0.62 and 0.71$)$, after transformation. The highest diversity was observed in group $\mathrm{D}\left(H^{\prime}=2.96\right)$, whereas that the rest of the assemblages did not show conspicuous differences between this attribute (from 2.72 to 2.88). The highest value of predominance was for group $\mathrm{A}(\lambda=0.22)$, while the rest of the groups had similar values (0.16 to 0.18), low in general (Table 6). 
(a)

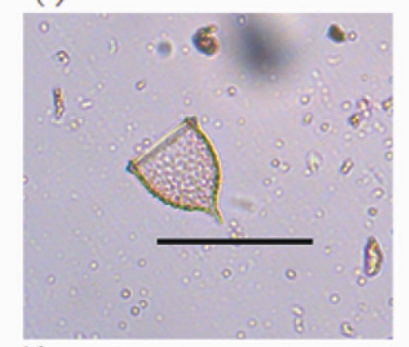

(d)

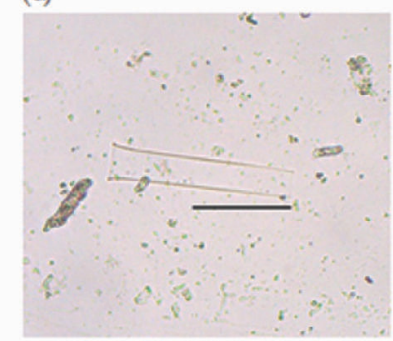

(g)

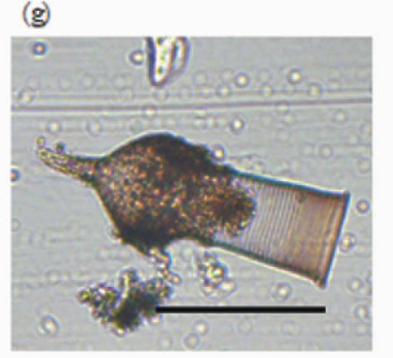

(b)

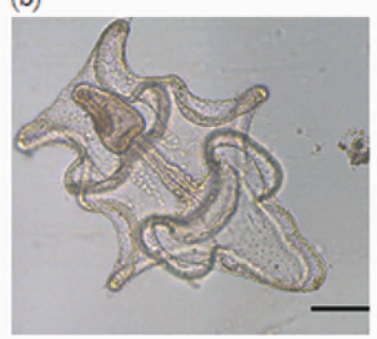

(e)

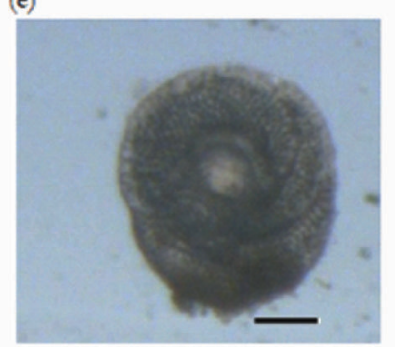

(h)

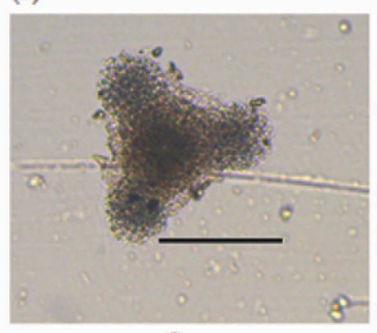

(j)

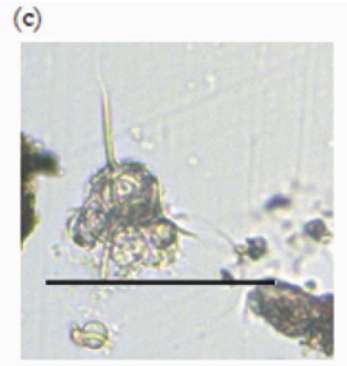

(f)

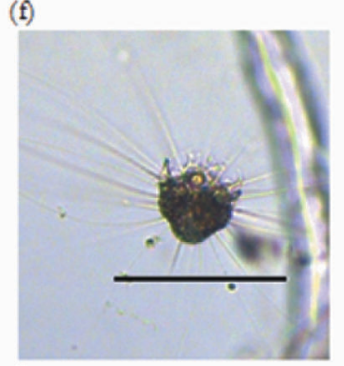

(i)

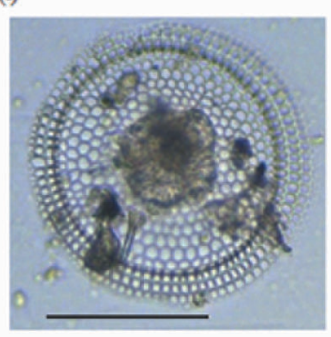

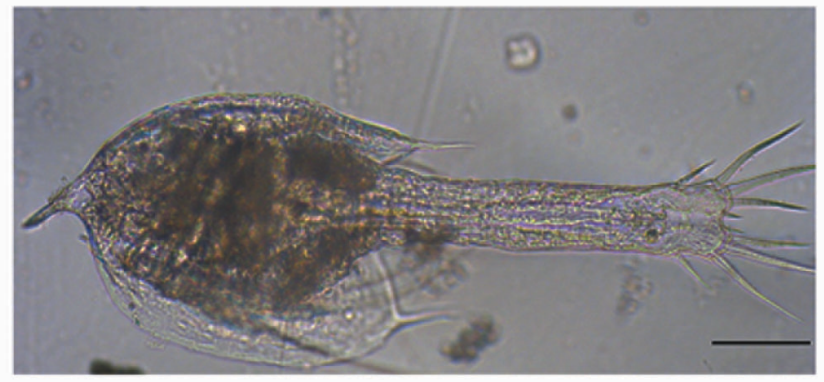

Figure 5. Species found exclusively in the mesophotic reef (assemblages C and D). (a) Epiplocylis blanda (b) Bipinnaria larvae, (c) Dictyophimus sp., (d) Eutintinnus spp., (e) Neoconorbina sp., (f) Pseudodictyophimus gracilpes, (g) Codonellopsis orthoceras, (h) Euchitonia sp., (i) Euceryphalus sestrodiscus, (j) Decapod larvae. $10 \mu \mathrm{m}$ scale bar.

\section{Conclusions}

The studied zooplankton community on seamount Bajo Frijol (PNNCPR - Colombian Caribbean) presented unique species that distinguished this community from others in upper zones. This particular might be influenced by depth and light limitations.

The mesophotic zooplankton community of Bajo Frijol is divided in two large assemblages, which presented exclusive species and different abundance and taxonomic composition. All of these are likely shaped by submarine current patterns that may have caused segregation of oceanic and typically neritic species at the north (group D), and the presence of oceanic and warm water 
Table 6. Mean ecological attributes by assemblage. Richness $(S)$, Density $(N)$, Pielou evenness $\left(J^{\prime}\right)$, ShannonWienner diversity $\left(H^{\prime}\right)$, Simpson dominance $(\lambda \pm$ S.E).

\begin{tabular}{cccccc}
\hline Group & $S$ & $N$ & $J^{\prime}$ & $H^{\prime}$ & $\lambda$ \\
\hline A & 79 & 45750 & 0.62 & 2.72 & 0.22 \\
B & 57 & 12250 & 0.71 & 2.88 & 0.18 \\
C & $75.00 \pm 4.70$ & $13065.00 \pm 453.91$ & $0.66 \pm 0.02$ & $2.85 \pm 0.12$ & $0.18 \pm 0.03$ \\
D & 71 & 9757 & 0.69 & 2.96 & 0.16 \\
\hline
\end{tabular}

species at the center-south (group C). In addition, the known vertical distribution range of the tintinnid $U$. hyalina could be broadened, because it was found $15 \mathrm{~m}$ to $30 \mathrm{~m}$ deeper than in most reports.

Given that this research was developed in a marine protected area, it is important to further study the dynamics of the zooplankton community on seamount Bajo Frijol, and to extend it to other areas within the park. For this reason, the results of this study were used to establish the monitoring and follow-up program for PNNCPR.

\section{Acknowledgements}

This manuscript is a product of the project entitled "Preliminary study of the planktonic and benthic communities of the mesophotic reef of Bajo Frijol at the PNNCPR" endorsed by National Natural Parks of Colombia (memorandum 20152200002063 11-25-15) and supported by the Research Vice-chancellor of the University of Cartagena, through the Plan de Fortalecimiento Act 024-2019 and the internal research project grant 2420. Authors thank to PNNCPR personnel for their technical support in building collection devices and in conducting samplings. Authors would like to acknowledge Deibis Seguro and Juan Vega for their technical support and photographs in the field and to engineer Fabian del Valle, for his graphic design and illustrations of the sampling device.

\section{Conflict of interest}

Authors declare having no conflict of interest.

\section{References}

Alonso D, Vides M, Cedeño C, Marrugo M, Henao A, Sánchez JA, Dueñas L, Andrade J, González F, Gómez M. Parque Nacional Natural Corales de Profundidad: descripción de comunidades coralinas y fauna asociada. Serie de Publicaciones Generales del Invemar No. 88, Santa Marta, COLOMBIA. 2015.

Anderson D. Barnacles. Structure, function, development and evolution. Chapman \& Hall, London, UK. 1994.

Andradi-Brown D, Head C, Exton D, Hunt C, Hendrix A, Gress E, Rodgers A. Identifying zooplankton community changes between shallow and upper mesophotic reefs on the Mesoamerican Barrier Reef, Caribbean, PeerJ-Life \& Environment, 5: e2853, 2016.

doi: $10.7717 /$ peerj.2853 
Armstrong H, Brasier M. Microfossile 2d edition. Blackwell publishing, Oxford, UK. 2005.

Baéz-Polo A. Manual de métodos de ecosistemas marinos y costeros con miras a establecer impactos ambientales. Convenio para establecer el fortalecimiento de los métodos de investigación marina para actividades costa afuera por parte del sector de hidrocarburos. Invemar-ANH, Santa Marta, COLOMBIA. 2013.

Bejarano I, Appeldoorn R, Nemeth M. Fishes associated with mesophotic coral ecosystems in La Parguera, Puerto Rico, Coral reefs, 33: 313-328, 2014.

doi: $10.1007 / \mathrm{s} 00338-014-1125-6$

Bernal A, Zea S. Variaciones nictemerales en la comunidad del zooplancton de la bahía de Santa Marta, Mar Caribe colombiano, Anales del Instituto de Investigaciones Marinas de Punta de Betin, 22: 5-20. 1993.

doi: 10.25268/bimc.invemar.1993.22.0.403

Bessell-Browne P, Stat M, Thomson D, Clode P. Coscinaraea marshae corals that have survived prolonged bleaching exhibit signs of increased heterotrophic feeding, Coral Reefs, 33(3): 795-804. 2014.

doi: $10.1007 / \mathrm{s} 00338-014-1156-\mathrm{z}$

Boltovskoy D. Atlas del zooplancton del Atlántico sudoccidental y métodos de trabajo con el zooplancton marino, INIDEP, Mar del Plata. ARGENTINA. 1981.

Carrillo-Baltodano A, Morales-Ramírez A. Changes in abundance and composition of a Caribbean coral reef zooplankton community after 25 years, Revista de Biología Tropical, 64(3): 1029-1040. 2016.

doi: $10.15517 /$ RBT.V64I3.21449

Clarke K, Gorley R, Somerfield P, Warwick R. Change in marine communities: An approach to statistical analysis and interpretation, PRIMER-E Ltd, $3 \mathrm{ed}$, UK. 2014.

Chasqui L, Gonzalez J. Peces registrados en ambientes mesofóticos de Bajo Frijol, la porción más somera del Parque Nacional Natural Corales de Profundidad, usando buceo técnico CCR, Boletín de Investigaciones Marinas y Costeras, 48(1): 89-101, 2019.

doi: 10.25268/bimc.invemar.2019.48.1.759

Contreras-Vega L, Henao-Castro A, Navas GR, Criales MI, Marrugo M. Dispositivo de recolección para zooplancton asociado a arrecifes de corales mesofóticos, Boletín de Investigaciones Marinas y Costeras, 49(SuplEsp): 243-250. 2020.

doi: 10.25268/bimc.invemar.2020.49.SuplEsp.1043

Costa S. Atlas de zooplâncton da região central da zona econômica exclusiva brasileira. Volumen 21 de serie livros. Museu Nacional, BRASIL. 2006.

Dolven J, Skjerpen H. An online micropaleontology data base: Radiolaria.org, Eclogae Geologicae Helvetiae, 99(1): 63-66. 2007.

doi: $10.1007 / \mathrm{s} 00015-006-0602-5$

Enrichetti F, Bo M, Morri C, Montefalcone M, Toma M, Bavestrello G, Tunesi L, Canese S, Giusti M, Salvati E, Bertolotto R, Biachi C. Assessing the environmental status of temperate mesophotic reefs: A new integrated methodological approach, Ecological Indicators, 102: 218-229. 2019.

doi: 10.1016/j.ecolind.2019.02.028 
Fernandes L. Tintininos (Ciliophora, Tintinnina) de águas subtropicais na região Sueste-Sul do Brasil. II. Famílias Dictyocystidae, Rhabdonellidae, Tintinnidae e Xystonellidae, Revista Brasileira de Zoologia, 21(3): 605-628. 2004a.

doi: 10.1590/S0101-81752004000300024

Fernandes L. Tintininos (Ciliophora, Tintinnina) de águas subtropicais na região Sueste-Sul do Brasil. I. Famílias Codonellidae, Codonellopsidae, Coxliellidae, Cyttarocylidae, Epiplocylidae, Petalotrichidae, Ptychocylidae, Tintinnididae e Undellidae Revista Brasileira de Zoologia, 21(3): 557-576. 2004b.

doi: $10.1590 / \mathrm{S} 0101-81752004000300019$

Figueroa S, Marchant M, Giglio S, Ramirez M. Foraminiferos bentónicos rotalinidos del centro

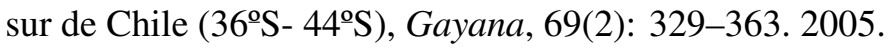

doi: $10.4067 / \mathrm{S} 0717-65382005000200013$

Gasca R, Castellanos I. Zooplancton de la Bahía de Chetumal, Mar Caribe, México, Revista de Biología Tropical, 41(3): 619-625. 1993.

https://revistas.ucr.ac.cr/index.php/rbt/article/view/23979/24130

Gutiérrez J. Estructura vertical del zooplancton oceánico del mar Caribe Colombiano, Trabajo de Grado Maestría. Universidad Nacional de Colombia, Bogota, COLOMBIA, 2010.

https://repositorio.unal.edu.co/handle/unal/10105

Heidelberg K, Sebens K, Purcell J. Composition and sources of near reef zooplankton on a Jamaican forereef along with implication for coral feeding, Coral Reef, 23: 263-276. 2004. doi: 10.1007/s00338-004-0375-0

Hernandez-Trujillo S, Esqueda- Escarcega G, Hernandez- Alfonso J, Pacheco- Chavez R. Variación diaria de la abundancia del zooplancton en Bahia Magdalena, B. C. S. Mexico, Revista Mexicana de Biodiversidad, 81: 913-920. 2010.

doi: 10.22201/ib.20078706e.2010.003.661

Johnson W, Allen D. Zooplankton of the Atlantic and Gulf coasts: A guide to their identification and ecology. The Johns Hopkins University Press, Maryland, USA. 2005.

Kaandorp J. Rocky substrate communities of the infralittoral fringe of the Boulonnais coast, NW France: a quantitative survey, Marine Biology, 92: 255-265. 1986.

doi: 10.1007/BF00392843

Kahng S, Copus J, Wagner D. Recent advances in the ecology of mesophotic coral ecosystems (MCEs), Current Opinion in Environmental Sustainability, 7: 72-81. 2014. doi: $10.1016 /$ j.cosust.2013.11.019

Kahng S, Garcia-Sais J, Spalding H, Brokovich E, Wagner D, Weil E, Hinderstein L, Toonen R. Community ecology of mesophotic coral reef ecosystems, Coral reef, 29: 255-275. 2010. doi: 10.1007/s00338-010-0593-6

Laverick J, Andradi-Brown D, Rogers A. Using light-dependent scleractinia to define the upper boundary of mesophotic coral ecosystems on the reefs of Utila, Honduras, PLoS ONE, 12(8): e0183075. 2017.

doi: 10.1371/journal.pone.0183075 
Lesser M, Slattery M, Leichter J. Ecology of mesophotic coral reefs, Journal of Experimental Marine Biology and Ecology, 375: 1-8. 2009.

doi: 10.1016/j.jembe.2009.05.009

Longhurst A. Relationship between diversity and the vertical structure of the upper ocean, DeepSea Research, 32: 1535-1570. 1985. doi: 10.1016/0198-0149(85)90102-5

Lorda J, Athié G, Camacho V, Daessle L, Molina O. The relationship between zooplankton distribution and hydrography in oceanic waters of the Southern Gulf of Mexico, Journal of Marine Systems, 192: 28-41. 2019. doi: 10.1016/j.jmarsys.2018.12.009

MacKenzie K, Roberston D, Adams J, Altieri A, Turner B. Structure and nutrient transfer in a tropical pelagic upwelling food web: From isoscapes to the whole ecosystem, Progress in Oceanography, 178: 102-145. 2019.

doi: 10.1016/j.pocean.2019.102145

Marín B, Lodeiros C, Figueroa D, Marquez B. Distribución vertical y abundancia estacional del microzooplancton y su relación con los factores ambientales en Turpialito, Golfo de Cariaco, Venezuela, Revista Científica FCV-LUZ, 14 (2): 133-139. 2004.

http://www.saber.ula.ve/bitstream/handle/123456789/28084/art5.pdf?sequence=2\& isAllowed $=\mathrm{y}$

Medellín-Mora J, Martínez-Ramírez O. Distribución del mesozooplancton en aguas oceánicas del mar caribe colombiano durante mayo y junio de 2008, 120-148. In: Navas GR, SeguraQuintero C, Garrido-Linares M, Benavides-Serrato M, Alonso D (eds.), Biodiversidad del margen continental del Caribe colombiano, Serie de publicaciones especiales, Invemar, número 20, Santa Marta, COLOMBIA, 2010.

Morales D, Rocha V, Oliva B. Geomorfología de los fondos submarinos del Parque Nacional Natural Corales de Profundidad, mar Caribe colombiano, Boletín de Investigaciones Marinas y Costeras. 46(2): 73-90. 2017.

doi: 10.25268/bimc.invemar.2017.46.2.727

Navas GR, Vides M, Díaz-Ruiz M. Ensamblajes faunísticos de la plataforma y talud superior del mar Caribe colombiano, 355-390. In: Navas GR, Segura-Quintero C, Garrido-Linares M, Benavides-Serrato M, Alonso D (eds.), Biodiversidad del margen continental del Caribe colombiano, Serie de publicaciones especiales, Invemar, número 20, Santa Marta, COLOMBIA, 2010 .

Nakajima R, Yamazaki H, Lewis L, Khen A, Smith J, Nakatomi N, Kurihara H. Planktonic trophic structure in a coral reef ecosystem -Grazing versus microbial food webs and the production of mesozooplankton, Progress in Oceanography, 156: 104-120. 2017.

doi: 10.1016/j.rsma.2015.08.016

Neumann-Leitão S, Eskinazi E, De Oliveira L, Do Nascimento-Viera D, Nogueira M, Schwamborn R. Diversity and distribution of the mosozooplankton in the tropical Southwestern Atlantic, Journal of Plankton Research, 30(7): 795-805, 2008

doi: plankt/fbn040

Universitas Scientiarum Vol. 26(3):281-300

http://ciencias.javeriana.edu.co/investigacion/universitas-scientiarum 
Nir O, Gruber D, Shemesh E, Glasser E, Tchernov D. Seasonal Mesophotic Coral Bleaching of Stylophora pistillatain the Northern Red Sea, PLoS One, 9(1): e84968. 2014. doi: 10.1371/journal.pone.0084968

Pierce R, Turner J. Global biogeography of marine tintinnids, Marine Ecology Progress Series, 94: 11-26. 1993.

doi: $10.3354 /$ meps094011

Riviera D. Dinoflagelados e tintinídeos da região central da zona econômica exclusiva brasileira: Guía de identificaçao. Volumen 22 de serie livros. Museu Nacional, BRASIL, 2006.

Sánchez JA, Gonzalez-Zapata F, Dueñas L, Andrade J, Pico-Vargas A, Vergara D, Sarmiento A, Bolaños N. Corals in the mesophotic zone (40-115 m) at the barrier reef complex from San Andres island (Southwestern Caribbean), Frontiers in Marine Sciences, 2019. doi: 10.3389/fmars.2019.00536

Scott A, Pawlik J. A review of the sponge increase hypothesis for Caribbean mesophotic reefs, Marine Biodiversity, 49: 1073-1083. 2019.

doi: 10.1007/s12526-018-0904-7

Stich H, Lampert W. Predator evasion as an explanation of diurnal vertical migration by zooplankton, Nature, 293: 396-398. 1981.

doi: $10.1038 / 293396 a 0$

Semmler R, Hoot W, Reaka ML. Are mesophotic coral ecosystems distinct communities and can they serve as refugia for shallow reefs?, Coral Reefs, 36: 433-444. 2017

doi: 10.1007/s00338-016-1530-0

Shlesinger T, Grinblat M, Rapuano H, Amit T, Loya Y. Can mesophotic reefs replenish shallow reefs? Reduced coral reproductive performance casts a doubt, Ecology, 99: 421-437. 2018. doi: $10.1002 /$ ecy.2098

Thompson G, Alder V, Boltovskoy D, Brandini F. Abundance and biogeography of tintinnids (Ciliophora) and associated microplankton in the Southwestern Atlantic Ocean, Journal of Plankton Research, 21(7): 1265-1298. 1999.

doi: $10.1093 /$ plankt/21.7.1265

Thompson G, Dinofrio E, Alder V. Structure, abundance and biomass size spectra of copepods and other zooplankton communities in upper waters of the Southwestern Atlantic Ocean during summer, Journal of Plankton Research, 35(3), 610-629. 2013.

doi: 10.1093/plankt/fbt014

Thompson G. Distribución y abundancia del microzooplancton en el Atlántico suroccidental, con especial énfasis en la biogeografía de Tintinnia (Protozoa: Ciliata), Tesis Doctoral, University of Buenos Aires, Argentina. 2001.

https://bibliotecadigital.exactas.uba.ar/download/tesis/tesis_n3383_Thompson.pdf

Vanegas M, Arregocés L. Aportes al conocimiento de la riqueza de los tintínidos (Protozoa: Ciliophora) de aguas superficiales del Caribe colombiano, Boletín Científico CIOH, 33: 107-121. 2015.

doi: $10.26640 / 22159045.281$

WORMS Editorial Board. World Register of Marine Species. 2017

doi: $10.14284 / 170$ 
Zaret T, Suffern J. Vertical migration in zooplankton as predator avoidance mechanism, Limnology and Oceanography, 21(6): 808-813. 1976.

doi: 10.4319/lo.1976.21.6.0804

Zheng Z. Marine Planktology. China Ocean Press, Hong Kong, CHINA. 1989. 
Distribución de zooplankton en un hábitat de arrecifes coralinos mesofóticos en la montaña submarina Bajo Fríjol, Caribe Colombiano

Resumen: Los ecosistemas coralinos mesofóticos (MCEs) albergan comunidades únicas. Debido a que en estos ambientes las zooxantelas coralinas se caracterizan por una baja tasa fotosintética, el zooplancton es allí la principal fuente alimenticia. Estos MCEs no han sido suficientemente estudiados debido al alto costo de las tecnologías de investigación disponibles actualmente, por lo cual estos esfuerzos siguen siendo un desafío. El propósito de este trabajo fue estudiar la comunidad de zooplancton asociada a los MCEs en la montaña marina Bajo Fríjol dentro del Parque Nacional Natural Corales de Profundidad (frente a la costa caribe colombiana) y comparar su composición con la de partes más someras de la columna de agua. Se tomaron tres muestras, filtrando $24 \mathrm{~L}$ de agua de mar (por medio de una malla de $45 \mu \mathrm{m}$ ) en cada estación con un dispositivo diseñado para colectar zooplancton justo encima del sustrato arrecifal. Se obtuvieron la composición taxonómica, la densidad y la abundancia relativa. Se realizó un análisis de similitud, complementado con un cluster, un EMD y un test Kandoorp modificado. Los análisis mostraron claras diferencias entre las muestras de la columna de agua y las tomadas cerca del arrecife. También mostraron la separación de la comunidad en dos grandes grupos: norte y centro-sur, ambos con especies únicas.

Palabras Clave: corales de aguas profundas; áreas protegidas de aguas profundo; corales mesofóticos; ecosistemas mesofóticos; comunidad de zooplancton; distribución de zooplancton.

Distribuição de zooplâncton num habitat de recife de coral mesofótico no monte submarino Bajo Frijol no caribe colombiano

Resumo: Os ecossistemas de corais mesofóticos (ECM) abrigam comunidades únicas. Dado que as zooxantelas coralinas nesses ambientes possuem baixa taxa fotossintética, o zooplâncton é o principal recurso alimentar dos ECMs. Estudar estes ecossistemas é um desafio por causa do alto custo das tecnologias de avaliação. O objetivo deste trabalho foi estudar a comunidade de zooplâncton associada aos ECMs do monte submarino Bajo Friol, localizado no parque nacional natural "Corales de Profundidad", ao largo da costa do Caribe colombiano e comparar sua composição com aquela de ecossistemas coralinos de partes mais rasas da coluna d'água. Foram coletadas três amostras filtrando $24 \mathrm{~L}$ de água de mar (através de uma malha de $45 \mu \mathrm{m}$ ) em cada estação usando um dispositivo desenhado para coletar zooplâncton em cima do substrato do recife. Obtivemos a composição taxonômica, densidade e abundância relativa. Foi feita uma análise de semelhança complementada com um cluster, um MDS e um teste de Kandroop modificado. A análise mostrou diferenças claras entre as amostras da coluna d'água e as do recife. Também mostrou a separação da comunidade entre dois grandes grupos: norte e centro-sul, cada um com espécies únicas.

Palavras-chave: alto mar; áreas protegidas em alto mar; corais mesofóticos; ecossistemas mesofóticos; comunidade de zooplâncton; distribuição de zooplâncton. 
Laura Contreras-Vega Biologist, MSc in Marine Sciences candidate, with experience in taxonomy and ecology of planktoniccommunities fromdifferent environments, such as coral reefs, mesophotic ecosystems, pelagic environments,estuariesand freshwater. She also participated in the analysis of zooplankton samples collected from the 1rst Colombian Antarctic Expedition.

ORCID: 0000-0003-4335-7387

Alejandro Henao-Castro Marine Biologist, MSc in Marine Sciences, part-time lecturerof the University of Cartagena and University of Sinú, withanextensive experience in the study of population and community ecology ofshallow, mesophotic and deep coral reef ecosystems in the Colombian Caribbean.

ORCID: 0000-0002-4125-765x

Gabriel R. Navas Suarez Colombian Marine Biologist, MSc and Ph.D in Marine Biology. Currently a full-timelecturer at the University of Cartagena, and Head of the Hydrobiology research group from Minciencias. During his scientific career, he had been head researcher and co-researcher in more than 20 scientific projects, mainly focused on marine biology and ecology.

ORCID: 0000-0001-9554-6345 